\title{
Challenges of Accountability in Resource-Poor Contexts: Lessons about Invited Spaces from Karnataka's Village Health Committees
}

\begin{abstract}
Invited spaces have been discussed by development scholars and policymakers as a new and important means of promoting accountability in primary healthcare. Although numerous experiments have been initiated to establish such spaces in resource-poor contexts, we still have little understanding of how these spaces are used and their effectiveness. Based on our longitudinal study of the Village Health Sanitation and Nutrition Committees (VHSNCs) in Karnataka, we trace changes that have occurred in the frequency and quality of interactions between state, political and civil society committee participants as they come to understand the possibilities afforded to them, work out tactics and develop a set of practices that make them accountable to each other for improving village health. Our findings suggest that strengthening accountability within invited spaces can form an important basis for improving the primary healthcare system with implications for research and policy.
\end{abstract}

Keywords: health services, human development, popular participation, village health committee 


\section{Main Text}

\section{Introduction}

Recent years have witnessed a wave of reforms intended to create institutionalized or 'invited' spaces for citizen to participate in monitoring and directing public service delivery to address the challenges that exist with conventional accountability systems (Gaventa, 2004;). On one hand these spaces have a semi-autonomous existence outside the institutions of the state's formal political and bureaucratic apparatus encouraging citizen participation, particularly of marginalized groups. On the other, they are partially embedded within the institutional apparatus of the state providing scope for citizens to participate in the planning, budgeting and monitoring of public programmes (Cornwall, 2004;).

Building on earlier attempts at creating deliberative democratic institutions, invited spaces offer a range of mechanisms for citizen engagement. One of the most internationally cited example of invited spaces is participatory budgeting conceptualized in Porto Alegre in Brazil in 1989 and implemented across Latin America and beyond. With this type of reform, a proportion of a national or local budget is allocated to participatory process in which citizens, with the help of relevant experts, are invited to lobby for initiatives they consider to be of public value. The community is then invited to vote online or in person and those ideas that secure the most votes are planned and implemented (Novo \& Leubolt, 2005). A second example of invited spaces are social audits which enable citizens to draw on public domain information to participate in public hearings and use this information to pressurize public officials to respond to charges of wrongdoing. The state of Andhra Pradesh in India has been a pioneer of social audits by proactively incorporating them into the implementation and monitoring of the National Rural 
Employment Guarantee Act (a national law that guarantees every citizen of rural India 100 days of work) and of other line department programmes (Aiyar, 2010).

While governments are actively working towards introducing new invited spaces, there is still poor understanding of how they are used and their effectiveness in terms of strengthening accountability (Aiyar, 2010). As scholars have noted, there has been a tendency in writing on these participatory governance forums to focus mainly on citizen engagement with less attention given to the critical role that state actors play in improved service delivery (Cornwall, 2002; Gaventa, 2004). In this paper we aim to contribute to the discourse on invited spaces by stressing the importance of strengthening inter-actor accountability ${ }^{1}$ within these spaces with particular reference to health committees which have been established at village or facility level in many resource-poor contexts such as India, Tanzania, Bangladesh and South Africa (George, 2009). We study India's Village Health, Sanitation and Nutrition Committees (VHSNCs) ${ }^{2}$ established by the central government in 2008 to improve accountability in primary healthcare (NRHM, 2013).

In the next section, we draw on relevant literature from development studies, health policy and public administration to develop a conceptual framework for our study. In the methodology section, we describe the relevance of our qualitative longitudinal approach for studying the actions that take place over time within the VHSNCs. Our findings section traces the activities that have occurred in twelve VHSNCs in Karnataka over a period of four years. The penultimate section then draws on the findings to explain how the activities that have taken place within the

\footnotetext{
${ }^{1}$ We interpret inter-actor accountability as accountability that emerges as a result of interactions between members of the VHSNC, rather than through hierarchical structures

${ }^{2}$ When established, these committees were called VHSNCs (Village Health and Sanitation Committees). Nutrition was added as an additional aspect of the committees' mandate resulting in the acronym VHSNC from 2014.
} 
VHSNCs constitute a strengthening of inter-actor accountability leading to a broader discussion of the theoretical and policy implications for primary healthcare delivery.

\section{Conceptualising Accountability in Invited Spaces}

The literature on invited spaces can be seen as part of the broader evolution of ideas on participation and accountability in development studies that has transformed orthodox thinking about public sector management. Much attention has been focused on identifying the challenges of establishing invited spaces in different political settings. For example, Roque \& Shankland (2007) describe the emergence of new participatory processes involving municipal corporations and local residents established to address complex urban management problems in Angola - a state with a tradition of centralized rule that has experienced a shift towards liberalization since 1991. The study traces how the legacy of authoritarian leadership acted to prevent the functioning of invited spaces by withholding financial resources and the implementation of legal frameworks. However, over time these spaces began to reflect the interests, agency and strategies of local actors as they learnt to engage with and propose solutions to local priorities. At a more micro level, studies have focused on the influence of political factors on equitable participation in invited spaces. In the context of rural India, Mohanty's (2007) ethnographic study examines the extent to which rural poor women are represented in village development committees created by the state to promote development and democracy. The study explains how rigid caste and patriarchal hierarchies continue to challenge meaningful participation of women in invited spaces. 
A central argument in the development studies literature is that participatory processes can only play a key role in strengthening accountability of government when local service delivery agents are provided with incentives to channel their expertise, decision-making autonomy and organizational capacity (Brett, 2003). From the experience of invited spaces, several studies support this point by showing how it is the engagement of local providers who plan and deliver services that is critical in improving accountability (Mahmud, 2007). Bottom-up theories from public administration literature provide a useful starting point for investigating the regular interactions that take place between service delivery agents in their encounters with citizens. Frontline workers who provide social services, termed by Lipsky (1980) as street-level bureaucrats, often resort to home-grown strategies and tactics in order to cope with the high demand for services together with vague and conflicting policy goals in situations of limited resources (Hupe \& Hill, 2007; Tummers et al., 2009). Aside from having to use discretion, service providers may be motivated to use discretion in order to maintain good social relations with citizens who participate in dialogue and show a high degree of civic awareness (Nielsen, 2006: Meyers \& Nielsen, 2012). In the context of Ghana, the use of discretion by health workers has allowed them to work with citizens to develop new policy approaches on health, sanitation and environmental issues building their confidence to oppose government projects that they feel would not work on the ground (Crook \& Ayee, 2006).

By substituting their discretion for policy targets, street level bureaucrats are subject to a unique accountability environment in which vertical structures of government are overshadowed as a result of the regular practices and processes through which public professionals and citizens encounter each other (Bartels, 2013; Tummers \& Bekkers, 2014). A unit of analysis in theorizing this localized accountability environment as identified by Nielsen (2007) is the level 
of communicative action which refers to the frequency and quality of interactions that take place between state and societal actors. Aside from their regular interactions with community members, the daily work of street-level bureaucrats is assumed to be embedded in their relationship with fellow street-level workers which serve as their primary reference group. At the same time, locally elected officials whose interest is to address community demands may also serve to endorse or oppose the actions of street-level bureaucrats (Gilson et al. 2005; May \& Winter, 2007). The frequency and quality of interactions that take place within invited spaces can be understood as a process that takes place over time in which state and societal actors learn to share knowledge, skills, norms and values through regular dialogue (Roberts, 2002). For example, in a study which investigated the functioning of watershed committees on the coast of the Gulf of Mexico, Pare \& Robles (2006) found that the building of shared responsibility amongst actors with different and contradictory interests occurred through an ongoing process of negotiation and engagement. Along similar lines, during the implementation of anti-poverty programmes in West Bengal, Veron et al. (2006) identified an emergent form of 'community accountability’ as forums were established which enabled frontline bureaucrats, local politicians and beneficiaries to build and share their interpretations of priorities and codes of practice for local development planning.

In this paper, we contribute to the growing discourse on accountability within invited spaces by focusing on community health committees which have been established in many low and middleincome countries. Recent studies have identified contextual factors that affect the functioning of health committees such as government funding,membership composition and socio-political features of the local community (McCoy et al., 2012; George et al., 2015). Ideas from streetlevel bureaucracy theory have been found useful to study the behavior of health workers within 
local committees, for example the different ways in which they use discretion in healthcare provision (Erasmus, 2014; Gilson, 2015). Increasingly, there is recognition that time and commitment are needed to develop trust and skills required for communities and health professionals to work together which has led to a call for focusing on longitudinal studies of health committees in specific contexts (Rifkin, 2014; Molyneux et al., 2012). However, aside from one study that identifies the contextual variations in how health committees function in Nigeria over a four-month duration (Abimbola et al., 2015), there is relatively little empirical information currently available on the unfolding process of accountability formation with these invited spaces.

Our empirical focus is on India's Village Health, Sanitation and Nutrition Committees (VHSNCs) established by the National Rural Health Mission (NRHM) in 2008 to improve accountability in primary healthcare. A number of cross-sectional studies have been undertaken in different states to compare VHSNC performance in terms of regularity of meetings, utilization of funds, health-seeking behavior of communities and links to the broader health infrastructure (Singh \& Purohit, 2012; Srivastava et al., 2016). To date, however, there have been no studies that view accountability in the VHSNCs as a process initially triggered by government and enacted over time through regularized interactions between state and societal actors as conceptualized in Figure 1. Our contribution is to study this process of enactment and to augment theoretical understanding of how invited spaces can improve health service delivery and promote development. 


\section{Methodology}

We adopt a qualitative case study approach informed by an interpretive philosophical position as an appropriate strategy for the early stages of research aimed at building theory on invited spaces (Myers 2013). Our motivation for adopting an interpretive approach follows Kaplan \& Maxwell's (1994) assertion that 'interpretive researchers do not predefine dependent and independent variables, but focus instead on the complexity of human sense-making as situation emerges’.

While treating the VHSNCs as a single case, our study was multi-site and longitudinal (Yanow et al., 2010) as we sought to identify and analyse the various activities that have taken place in twelve villages in Karnataka from January 2012 until December 2015. The key concepts that emerged from our review of the literature helped us to identify questions that guided the empirical work. First, we were interested in documenting changes in VHSNC frequency and membership over time in each village. Second, we were interested in identifying the extent to which activities and sub-activities were taking place regularly within each VHSNC over the duration of our study. Third, we sought to identify why some activities were more prevalent than others at different times during our study and the influence of some activities on the take-up of other activities.

Our main mode of data collection was through participant observation at VHSNC meetings which seemed to be a practical way for us to study how the committees were operating over a period of time whilst maintaining regular interaction with the people we observed. Most of the fieldwork was carried out by two locally-based and experienced Kannada-speaking ${ }^{3}$ researchers

\footnotetext{
${ }^{3}$ Kannada is the language spoken in Karnataka state
} 
who maintained regular contact with the committee members and with other villagers in the study sites in order to build a rapport and gain their trust. One of the authors based in Bangalore and whose mother tongue is Kannada regularly discussed the field notes with the local researchers whilst the other author based in the UK regularly received transcribed and translated notes. Communication between the authors and the field researchers took place both electronically and face-to-face when the team was together in Bangalore. While initially the field researchers noted everything that they observed, during the course of the study we were able to identify recurrent themes during the VHSNC meetings which helped us to compile an observational coding template showing key and sub-activities as shown in Table 1. In total, 213 meetings were attended in the 12 villages of Gumballi PHC during the four-year duration of the study. Every single meeting that took place was attended by at least one of the field researchers and narrative accounts of each meeting were transcribed and entered into a coding template file we called the VHSNC log which included a village-wise record of when meetings took place, who attended and the issues discussed. Towards the end of our study period in December 2015, we obtained some supplementary data from focus group discussions $(n=2)$ and interviews $(n=4)$ in a random selection of four villages which we used to validate our inferences from participant observation. Details of methods employed and questions asked are included in the Appendix.

Analysis of observation data occurred in an abductive fashion, as at each stage of study we sought the simplest and most likely explanation of our observations ( Magnani 2001). Alongside data collection we periodically reoriented our study based on emerging points of interest from the VHSNC meetings as presented in Table 1. We used our participant observation data to create an annual activity occurrence index for each village based on the number of occurrences of each activity during that year divided by the number of meetings that had taken place. Plotting 
activity data against time provided us with a visual representation of which activities were increasing in frequency (Figure 2). Statistical significance of the results was determined by carrying out a multilevel regression using log of the activity index as response, year as predictor and village as a random factor to assess whether any observed increase was significant at the $5 \%$ probability level. In order to explain the trend in the occurrence of activities we organized observation data into narratives of what went on in the different VHSNC meetings as representations of the actions and desires of its members. Over time, we began to see patterns emerging in terms of how individual activities affected each other which helped strengthen our analysis.

In this research, no data related to individual health conditions was collected. However, we recognized that we were collecting data on what could be sensitive aspects of health systems functioning and therefore all data obtained about the functioning of the VHSNCs has been kept anonymous with only members' roles disclosed. In addition, we sought approval from the LSE Research Ethics Committee at the commencement of our study and have continuously requested permission to observe and take notes during VHSNC meetings and from those who took part in focus group discussions and interviews.

\section{Describing the context}

The primary healthcare sector in India is often criticized for its lack of accountability to the community due to inadequate infrastructure, manpower shortages and lack of responsiveness to the priorities of low-income rural communities (Chaudhury et al., 2006). Since its establishment in 2005, a key mandate of the National Rural Health Mission (NRHM) has been to improve 
accountability by computerizing report generation at primary health centre level and providing a web-enabled interface for transmitting locally-generated information to higher echelons of the health administration (MOHFW, 2011). However, this type of intervention has been criticized as a reinforcement of the overly hierarchical system of accountability within the health administration rather than a mechanism for improving accountability to community members (George, 2009; Madon et al., 2010). In 2008, efforts were launched to make the system more accountable to the community by creating the VHSNC as a $15-20$ member sub-committee of the gram panchayat ${ }^{4}$ to specifically address village health, sanitation and nutrition needs. Each VHSNC was mandated to receive an annual untied grant of Rs. 10,000 (approximately US\$152) payable in three installments to be used for raising community awareness and for purchasing items to improve the health of the village. By 2011, 483,496 VHSNCs were formed in the country covering about 70\% of Indian villages (NRHM, 2011).

VHSNC members are nominated from a mix of government health workers, local political representatives and civil society representatives. NRHM guidelines stipulate that there should be $50 \%$ representation of women and significant participation from scheduled castes, scheduled tribes $^{5}$ and other citizen groups (GOI, 2005). A gram panchayat member is nominated as President of the VHSNC for a period of two years and serves as one of the account holders for the untied grant while other gram panchayat members may participate as members. Four members of the VHSNC are mandated to be state employees. One of these is an anganwadi worker, a female worker who specializes in providing basic healthcare and nutrition education to pre-school children under the Integrated Child Development Scheme run by the Ministry of

\footnotetext{
${ }^{4}$ The gram panchayat is a village council in which members are elected to serve for a 5-year term

${ }^{5}$ Scheduled caste/scheduled tribes are recognised as two historically disadvantaged groups in the Constitution of India
} 
Women and Child Development. A second state member is the ASHA ${ }^{6}$ worker - a local woman trained under the NRHM to act as a health educator and who serves as an important interface between the community and the health system. One ASHA worker is nominated as the Secretary and joint account-holder of the VHSNC fund while other ASHA workers may attend the committee as members. As unsalaried government employees, ASHAs receive an incentive of Rs.150 (approximately US\$2) for organising the VHSNC meeting and other performance-based compensation from the gram panchayat for meeting targets such as the for escorting a certain number of pregnant women to the clinic. State employees in the VHSNC also include male and female health workers - the latter supervising the ASHA worker, as well as a teacher from the village school. In order to ensure that citizens with the least power and voice are represented, NRHM guidelines indicate that community representatives from marginalized groups should serve on the VHSNCs (GOI, 2005). These include mainly female representatives of self-help groups that comprise of below-poverty-line women working to establish income-generating activities as well as representatives from scheduled caste, scheduled tribe and other backward classes. While not formally members of the VHSNCs, an increasing number of pregnant women and new mothers have been attending the meetings in all the villages studied. Table 2 summarises the composition of VHSNC members and attendees and their roles within the village and in the committee.

Our case is located in Chamarajnagar district, one of the less developed parts of the state of Karnataka, $180 \mathrm{~km}$. south of Bangalore city. Our empirical work took place in the area of Gumballi primary health centre (PHC) which serves approximately 22,400 people in 12 villages and where approximately half the population belongs to scheduled caste and scheduled tribes

\footnotetext{
${ }^{6}$ ASHA is an acronym for Accredited Social Health Activist
} 
with agriculture and animal husbandry comprising the main economic activity for the many landless laborer families. The villages vary in size with population ranging from approximately 700 to 1,500. Karuna Trust, a locally prominent NGO established in 1986, working to improve health, education and livelihoods of rural communities, has been active in this area. In 1996, the Trust negotiated with the state government to take over the running of Gumballi PHC (together with one PHC in each of the other 30 districts in Karnataka). The scope of the Trust's work in Gumballi PHC has extended to activities such as encouraging community engagement in health through the regular running of workshops and capacity-building sessions for the VHSNCs.

\section{Activities occurring within Gumballi’s VHSNCs}

In this section, we describe activities of the VHSNCs in our study villages over a period of four years from January 2012 to December 2015. Table 3 provides data on the number of committee meetings held in each village. Overall, we find an increase in the frequency of meetings over this period in the majority of villages. In 2014, all villages saw a reduction in the number of meetings due to delays experienced in transferring the untied grant as a consequence of the general election campaign. By 2015, the majority of villages were holding meetings every two months and there was an almost two-fold increase in the average number of attendees as Table 3 indicates. We observed the inclusion of new participating members such as the village waterman, pregnant women and new mothers in every VHSNC meeting held since January 2015 together with a substantial increase in the percentage of marginalized community representatives who attend meetings. In the rest of this section, we describe our observations of the occurrence and nature of key activities that have taken place. 


\section{(i) Raising health awareness}

Our data shows that there has been a significant increase in the occurrence of activities related to raising health awareness during the study period as shown in Figure 2a. This has included talks given by ANM and ASHA worker on specific diseases such as malaria, dengue fever and leprosy as well as on sanitation. The anganwadi worker has focused on providing counselling on nutrition and childhood diseases for pregnant and lactating mothers. During 2012, even in the best performing villages in terms of health awareness activity, talks were only given on two occasions during the course of the year. However, in 2012 and 2013 all twelve villages were observed to raise health awareness by displaying boards about the VHSNC in strategic locations such as outside the school and anganwadi centre

From January 2015, we observed an increase in health awareness talks in all our study villages as the focus on specific diseases was expanded to include sanitation and cleanliness. One important issue discussed during VHSNC meetings related to the need for pregnant women to wear slippers before going to the toilet to avoid risk of bacteria caused by solid waste entering the body and leading to infection. While earlier this issue was raised in only seven out of twelve villages, in 2015 we observed that all twelve villages were discussing this topic at least once over the course of the year. A second issue discussed in over half of villages during VHSNC meetings held in 2015 related to creating awareness about how to avoid the spread of communicable diseases during the rainy season by drinking pure and boiled water, avoiding eating outside food and refraining from keeping food in open containers in the house. 
During the first three years of our study, raising health awareness was an activity initiated exclusively by health and anganwadi workers but from 2015 we observed that in more than half of our study villages other members were taking the lead. For example, the waterman frequently raised awareness about the need for cleaning and chlorination of water tanks and the school teacher began to emphasize the need for maintaining cleanliness and good hygiene both inside the school building and its surrounding area. In four of our study villages, we noted that citizen representative VHSNC members as well as non-member participants such as pregnant women and mothers have started asking health workers to explain certain government schemes and demonstrating an increasing awareness about cleanliness and hygiene within the household and vicinity. For example, a village resident who took part in a focus group discussion we held in June 2015 in Dasanahundi commented, "first we have to clean our house, then places near our house. Otherwise if our neighbouring places are dirty then mosquito there may come and bite the person who has cleaned his house."i

\section{(ii) Deciding on untied grant usage}

Taking decisions on how to spend the untied grant was a high occurrence activity within all VHSNCs even at the commencement of our study in 2012 and this has remained so throughout the duration of our research as depicted in Figure 2b. In some years, we observed that there has been a greater focus on particular items of expenditure compared to other years. For example, in 2012 and 2013 we observed that in half of the villages, the ANM, ASHA or anganwadi workers were the main committee members who requested authorization to purchase one-off fixed items of furniture such as tables and chairs for the anganwadi centre. In ten study villages, items of health equipment such as thermometers and weighing scales for the school and anganwadi centre, or blood smear instruments for household visits were purchased at least once during this 
period. In contrast, only four villages needed to purchase such items from the untied grant in 2015 in order to replace old equipment. In contrast, a few decisions on untied grant usage have only taken place in the second half of our study period. For example, since 2013 we observed that ASHA workers have started to request payment from the untied grant for expenses incurred whilst conducting health surveys such as for dengue and malaria at village level with ten villages conducting surveys at least once every year. Similarly, from 2014, the anganwadi workers started to request funds to purchase supplements for improving child health and oral rehydration salts to control diarrhea as well as essential nutrients such as Vitamin B Complex with six villages taking this decision at least once over the past two years.

There has been a gradual increase in untied grant usage decisions related to sanitation over the four years of our study. Different VHSNC members have made requests to the President to sanction a variety of expenses related to the purchase of chlorination powder to clean drinking water storage areas, lime powder to avoid insects inside the water tank, bleaching powder for drains, repair of rusty taps and clearing of garbage in the village. The input of the ANM, ASHA worker and waterman has been influential in issues related to village cleanliness while the school teacher and anganwadi worker have made specific requests to improve sanitation in and around the school building and anganwadi centre. The ASHA worker has had a major influence on decisions taken to purchase slippers for low-income pregnant women to avoid risk of infection. In 2012, six villages had taken decisions to spend on sanitation from the untied grant at least four times during the course of the year while in 2015 this had increased to ten villages. However, in the case of Yargamballi, the large size of this village has resulted in the over-spending of the untied grant on slippers for pregnant women leaving less funds for other priorities. As an ANM we interviewed from this village in June 2015 remarked, "in Yargamballi, the amount is not 
enough because even if we buy slippers for Rs. 5000 we can distribute it only to around twenty pregnant women and in a year there will be around fifty to sixty pregnant women and then we have few funds for keeping drinking water clean.”ii

(iii) Self-organising of the committee

We define self-organising activity in terms of tasks related to the scheduling, running and administration of meetings, as well as to increasing transparency and accountability in operational procedures within the VHSNC. Figure 2c reveals that there has been a significant increase in self-organising activity within the VHSNCs.

As a VHSNC member with office-bearing responsibilities, the ASHA worker who is nominated as the Secretary of the committee assumes responsibility for the scheduling and running of meetings. We observed that by 2013 nine of the twelve VHSNCs had scheduled committee meetings to take place on a fixed day each month and the Secretary would be proactive in contacting members to remind them to attend the next meeting. One of the villages where this did not hold was Gangavadi where during a focus group discussion held in June 2015, a scheduled tribe representative VHSNC member reported, "the meetings are not going well because the ASHA worker has not informed the committee members in advance. She is careless and not interested in organizing the meeting." ,iii When meetings took place we observed that in all villages the Secretary kept a register of attendees and commenced each meeting by recapping on the action points from the previous meeting. Over the course of our study, we observed that in five villages the President and Secretary VHSNC had taken the initiative to replace non-active members with other more committed participants. 
An increase in the transparency and accountability of VHSNC fund usage was observed during meetings through practices such as announcing the deposit of the untied grant and the new account balance, showing receipts of purchased items and distributing them so that members were assured that the money had been used as sanctioned. In 2013 these practices were observed in only two of the twelve villages at a regular interval of four or more times during the year, while in 2015 they were observed in nine villages at least four times during the year. By 2015, we also noticed that it had become common practice for villages to take signatures from beneficiaries who receive slippers to ensure that they are eligible and that they do not claim twice.

(iv) Planning and monitoring village health

Planning and monitoring within the VHSNCs is an activity that has increased in significance since 2012 as shown in Figure 2d. We noticed that there were different aspects to this activity at different times. In 2012, we observed that only seven out of twelve villages were involved in planning ahead to ensure the availability of safe drinking water during the summer months and for the village festival and reporting the malfunctioning of village sanitary works such as broken water pipes, rusty taps and missing overhead tank covers. By 2014, all villages used the VHSNCs at least once during the course of the year to plan for the removal of garbage in the village and to plan in advance for conducting surveys as commissioned by the government. While planning and monitoring during VHSNC meetings was an activity initially driven by either health workers or by Karuna Trust social workers, by 2015 we found that in all twelve villages other committee members such as teachers, village leaders and the waterman were more 
active. We found that these members were asking for drains to be cleaned, and school first aid box to be checked as well checking that rations given by the anganwadi worker to children complied with government prescription. In over half of the villages in 2015, either the waterman or the village leader were involved in ensuring that water sources were tested by the gram panchayat twice a year pre and post monsoon and by the PHC each month as per government regulations.

While NRHM guidelines state that a village health plan should be prepared every year by the VHSNC, this has so far not been done. Since 2015, Karuna Trust has been active in Gumballi PHC in terms of supporting the VHSNCs develop the necessary skills for this exercise conducting workshops to help members identifying the problems of health, sanitation and nutrition. Using a variety of diagrammatic participatory rural appraisal tools, members have taken part in identifying the location of social resources like drainage, toilets and roads, the availability and access of health facilities in the village, seasonal changes in livelihoods, and income and expenditure patterns amongst village residents. By the end of 2015, we observed that with the exception of Gangavadi, all villages routinely discussed the village health plan during VHSNC meetings. As an example of the perceived value of this planning activity, we noted the following comment made by the school teacher during the VHSNC meeting held in Komanapura in November 2015, “I am happy about the village health plan and feel that the participatory exercise had been useful for village development. Now, as follow up, we need to think of a way to analyse improvements in one year's time.”,iv 


\section{(v) Cross-sector integration}

Cross-sector integration refers to activities undertaken by the VHSNC that aim to strengthen relationships with other local bodies with the aim of improving village health. Starting as a low occurrence activity in 2012, there has been a gradual increase in its prevalence throughout the study period as depicted in Figure 2e. An early aspect of this integration that we observed in 2012 in all the twelve villages related to directives set by the taluk or district health administration for the VHSNC to follow such as for the placing of a board in the village or the conduct of a health survey.

A noticeable aspect of cross-sector integration from 2013 onwards has been requests made by the VHSNC to the gram panchayat for supporting a variety of sanitation requirements such as the clearing of garbage from the village and the cleaning of water tanks. In 2013, only six of the twelve villages made requests for financial assistance to the gram panchayat during VHSNC meetings while in 2015 we observed that this occurred in all villages at least once during the course of the year with half of the villages managing to obtain extra funds. The importance of cross-sector integration between the VHSNC and the gram panchayat for improving village health came across in a remark by an ASHA worker during a focus group discussion held on $16^{\text {th }}$ June 2015 in Gangavadi, “if a tap is broken in the village, you cannot go and ask the panchayat office to get it repaired as it is a small sum, but if you want to build drainage, it is not possible because you need at least 3-4 thousand rupees so the gram panchayat would do that."v Alongside these improvements in cross-sector integration between VHSNCs and the gram panchayat we

observed an increase in the number of gram panchayat members attending meetings. Prior to 2014, only two of the twelve villages recorded the attendance of an extra gram panchayat member wheras from 2014 we observed that this was the case in four villages. 
An increasingly important aspect of cross-sector integration has been interaction between members of the VHSNC who work for different government departments, particularly the ASHA and anganwadi workers ${ }^{7}$ who share a common operational aim of improving the health of malnourished children in the village. While not observed in earlier years, in 2015 six of the twelve villages held discussions at least once during the course of the year about the need for closer integration between the ASHA worker identifying malnourished children in the village and the anganwadi worker then administering food supplements to those children. Cross-sector integration between the VHSNC and government is also seen to occur with increasing regularity as VHSNC members discuss the operationalization of government programmes relevant to improving village health ${ }^{8}$. We observed that before 2015, these programmes were discussed in only three villages, while in 2015 six villages brought up these programmes at least once during the course of the year.

\section{Interpreting accountability in the VHSNCs as stages of maturity}

The previous section presented an account of the activities that have taken place in the VHSNCs of Gumballi over a four-year duration. Supporting our earlier conceptualisation of accountability in invited spaces, we found that there was an increase in the frequency of VHSNC meetings and changes in the intentions and actions of VHSNC members regarding village health issues. Our aim in this section is to augment theoretical understanding of accountability in invited spaces by focusing on changes in the quality of interactions that have taken place between committee participants and other relevant organisations.

\footnotetext{
${ }^{7}$ The ASHA worker reports to the Health Department while the anganwadi worker reports to the Women and Child Development Department

${ }^{8}$ These schemes include the NRHM Janani Suraksha Yojana safe motherhood scheme, the Karnataka government Thayi Bhagya scheme providing maternal healthcare to below poverty line women and the NRHM Nirmal Bharat Abhiyan total sanitation programme
} 
In 2012, the two most prevalent activities occurring within the VHSNCs related to taking decisions on how to use the untied grant and activities related to self-organisation within the committee as members were initially motivated to attend meetings regularly in order to make use of the funds that were available. At this time, health workers were found to be more proactive than other members in driving the agenda for many of the activities that took place during VHSNC meetings. For example, spending decisions focused on the purchase of items such as thermometers and blood smear instruments so that the incidence of major diseases such as malaria and dengue fever could be detected earlier by health workers. In parallel, health workers were engaged in running health awareness sessions during VHSNC meetings informing members about these diseases, their symptoms and prevention. This information dissemination was supported by cross-sector integration in the form of directives by taluk and district health authorities to place notice boards and distribute leaflets about the VHSNC throughout the village. Planning and monitoring was a nascent activity at this time as health workers began to use the VHSNC to sensitize members about the need to ensure in advance that safe drinking water was available during the summer months and when village festivals took place.

By 2013, our data showed a rapid increase in the frequency of meetings and member attendance which coincided with changes in the quality of activities that took place. In terms of spending decisions, essential health equipment continued to be purchased but this was no longer the main spending category as new priorities came to be identified such as providing nutritional supplements for children and improving sanitation throughout the village to ensure safe drinking water. These changes in spending priorities were matched by new topics in health awareness sessions, for example directed at cautioning pregnant women to wear slippers before going to the toilet or outside to avoid risk of bacteria caused by solid waste entering the body and leading to 
infection. Our data showed an increase in planning and monitoring activity during this time, particularly with respect to larger projects involving repair of the village water tanks and clearing of garbage from village dustbins both of which fostered inter-sectoral collaboration with the gram panchayat.

While the amount of untied grant allocation has remained the same over the years, our findings show that the majority of villages have experienced a more diversified pattern of spending to include slippers for individual beneficiaries as well as a range of items related to health, sanitation and nutrition. The increased regularity of meetings improved cross-sector linkages with district health authorities who routinely entrust the conduct of health surveys to the VHSNCs. In parallel with multiple activities has been the increasing prevalence of selforganising activity aimed at greater transparency and accountability in operations as a shared responsibility. While in 2013 our data showed that practices such as disclosing the untied grant balance, showing receipts for purchased items and distributing purchased items during meetings were emergent practices, by 2015 they had become routinized alongside obtaining signatures of women beneficiaries upon receipt of slippers. Over time, our data reveals a more active participation in the committee by other members such as school teachers, village leaders, waterman and other civil society representatives. From 2015, in more than half of our study villages these members as well as non-member pregnant and lactating mothers have begun to share the responsibility of requesting information about health issues, monitoring water sources in the village and participating in developing the annual village health plan. This momentum has resulted in greater cross-sector integration with the gram panchayat in preparing the annual village health plan as a combined village development effort. 
We interpret the linkages between the five key activities observed in this study as stages of maturity in VHSNC functioning. For analytical purposes, we delineate this cycle into three main phases, each representing a higher stage of maturity as described in Figure 3. The first phase can be characterized by the initial identification and enrolment of VHSNC members as per government guidelines. Availability of the untied grant incentivizes members to establish basic procedures for recording the conduct of meetings and taking decisions on how to spend the monetary allotment. By the end of the first phase, regularity has been established in meeting frequency and attendance. The second phase is characterized by a more informed VHSNC as members begin to show a more active interest in the conduct of meetings and in raising awareness about health, sanitation and nutrition practices. Effective fund utilization includes a more diversified range of spending to reflect these practices leading to noticeable outcomes in terms of improved water quality and cleanliness. The third phase represents the current stage of VHSNCs in Gumballi where regular meetings take place in all twelve villages and practices have become institutionalized. This phase is characterized by the identification of larger issues such as long-term planning and monitoring and the involvement of external entities such as the gram panchayat and health department. A characteristic feature of this stage of maturity is that the VHSNCs demonstrates that it has the capacity for managing village health with strong potential to influence the wider health planning apparatus.

\section{Conclusion}


As India has climbed rapidly up the ladder of economic growth rates, it has fallen behind in the most basic of health measures such as maternal and child mortality (Dreze \& Sen, 2013). In particular, lack of adequate sanitation remains a serious contributing factor for poor health indices, for example approximately $60 \%$ of villages in Chamarajnagar district still have no latrines and $30-40 \%$ of villagers in Yelandur taluk ${ }^{9}$ lack awareness of the need for latrines and practice open defecation. India's NRHM has been instrumental in the constitution and design of the VHSNCs as invited spaces aimed at making the primary healthcare system more accountable to the community.

The existing literature on invited spaces in primary healthcare in low and middle-income countries has focused on identifying macro and micro-level contextual factors that affect the functioning of these committees, particularly in terms of equitable citizen participation. Our findings contribute to this discourse by responding to the call for longitudinal study in order to gain a deeper understanding of how village health committees emerge and evolve to create spaces for inter-actor accountability.

Our study found that the frequency and quality of interactions have improved over time as committee members have come to understand the possibilities afforded to them, work out tactics and develop a set of practices that make them accountable to each other for improving village health. We suggest that this local accountability environment within invited spaces can form an important basis for addressing the broader issue of making the primary healthcare system more accountable to the rural community it serves.

\footnotetext{
${ }^{9}$ Yelandur taluk is a sub-district of Chamarajnagar district where Gumballi PHC is located
} 
Our study suggests three areas where government policy should focus attention. First, within the VHSNCs, we have seen how usage of a relatively small untied grant has gone a long way towards addressing a variety of important village health, sanitation and nutrition issues through the engagement of local state and societal representatives. However, the continued timely and adequate disbursement of the untied grant is an issue that needs to be addressed by the government in order to enable the committees to plan ahead. Second, policymakers need to identify mechanisms through which the knowledge gained from the VHSNCs can be integrated with the health planning apparatus. While local-level linkages have started to emerge between the VHSNC, the gram panchayat and the health department, invited spaces need to be more directly recognized and granted legitimacy at the PHC level. For example, the PHC could act as a repository to compare and contrast the performance of individual VHSNCs within its jurisdiction and provide a forum for the sharing of experiences as part of a learning cycle. Third, policies are needed to support capacity-building of the VHSNCs regardless of whether they are government-run or managed by the Karuna Trust. Our study has been confined to Gumballi PHC where the Karuna Trust has been instrumental in building the capacity of the committees but this may not be the case in government-run PHCs that lie adjacent to Gumballi.

To conclude, we point to three research avenues that stem directly from our study of the VHSNCs in Gumballi which can contribute to strengthening our understanding of improving accountability in these invited spaces. First, there is so far only limited evidence about the VHSNCs having a positive impact on reducing the incidence of acute outbreaks of diseases calling for a more systematic and longitudinal analysis to correlate VHSNC activities with health indicators on diseases that are specifically affected by poor sanitation such as water-borne diseases like diarrhea and dysentery (Wilson, 2015). Second, economic and social divides at 
village level can affect equity in health access and need to be investigated through ethnographic study as there may be exclusions due to class, gender, age and ethnicity in the composition and participation of VHSNC members. Indeed, invited spaces do not exist in a vacuum but alongside unofficial spaces of everyday life and what happens in one space impinges on another as relations of power within and across spaces are constantly being reconfigured. Third, we suggest comparative studies across PHCs, taluks, districts, states within India and other countries in order to address the influence of contextual variables. For example, Karnataka has a relatively stronger legacy of decentralization and civic engagement in comparison with other Indian states. Within Karnataka, Gumballi PHC can be compared with a neighboring PHC to test the hypothesis that VHSNCs function better when supported by NGOs and to identify issues that could arise in other areas where NGOs are less active or inactive. Comparative research can also shed light on how differences in the way scheduled castes are treated in different states can affect access to basic health resources. Finally, country comparisons can be useful to identify how the institutional status of village health committees may affect outcome. In India, the VHSNCs are a subcommittee of the village council and are influenced by it while in Tanzania village health committees operate as parallel bodies with unclear jurisdiction.

The essential message we have tried to convey in this paper is that the promotion of accountability in invited spaces is a complex issue that cannot be designed from a distance. Indeed, this point refers not only to the primary healthcare sector but speaks to broader debates in development about technical, managerialist approaches to enhancing accountability in service delivery. We have argued that accountability must be accepted on a much deeper procedural level with a commitment to study the different stages of maturity through which activities involving state, political and societal representatives unfold. The success of these spaces is 
highly dependent on the perceptions and practices of local state actors in their encounters with citizens. Invited spaces are part of a shifting landscape in which longer term changes in the way citizens are involved in processes of governance may be taking root. In many cases, these initiatives have little or no immediate policy efficacy but patience is needed because tactics are being tried and alliances are being built and what participants bring into and take from these spaces may have many possibilities for them as actors in other spaces and more broadly for the practice of democratic accountability. 


\section{References}

Aiyar, Y. (2010) Invited Spaces, Invited Participation: Effects of greater participation on accountability in service delivery, India Review, 9 (2), pp. 204-229.

Abimbola, S., Molemodile, S., Okonkwo, O., Negin, J., Jan, S. and Martiniuk, A. (2014) 'The Government Cannot Do It Alone': Realist analysis of the minutes of community health committee meetings in Nigeria, Health Policy and Planning, 29, Suppl 2, ii29-ii39.

Bartels, K. (2013) Public Encounters: The history and future of face-to-face contact between public professionals and citizens, Public Administration, 91, 2, pp. 469-483.

Brett, E.A. (2003) Participation and Accountability in Development Management, The Journal of Development Studies, 40, 2, pp. 1-29.

Chaudhury, N., Hammer, J., Kremer, M., Muralidharan, K. and Rogers, F.H. (2006) Missing in Action: Teacher and health worker absence in developing countries, Journal of Economic Perspectives, 20 (1), pp. 91-116.

Cornwall, A. (2002) Making Spaces, Changing Places: Situating participation in development, IDS Working Paper, 170, Institute of Development Studies, University of Sussex.

Cornwall, A. (2004) New Democratic Spaces? The Politics and Dynamics of Institutionalised Participation, IDS Bulletin, 35 (2), pp. 1-10.

Crewett, W. (2015) Street-Level Bureaucrats at Work: A municipality-level institutional analysis of community-based natural resource management implementation practice in the pasture sector of Kyrgyzstan, Sustainability, 7, pp. 3146-3174.

Crook, R. and Ayee, J. (2006) Urban Service Partnerships, 'Street-level Bureaucrats’ and Environmental Sanitation in Kumasi and Accra, Ghana: Coping with organizational change in the public bureaucracy, Development Policy Review, 24, pp. 51-73.

Dreze, J. and Sen, A. (2013) An Uncertain Glory: India and its contradictions, Allen Lane, London.

Erasmus, E. (2014) The Use of Street-Level Bureaucracy Theory in Health Policy Analysis in Low and Middle-Income Countries: A meta-ethnographic synthesis, Health Policy and Planning, 29, pp. iii70-iii78.

Gaventa, J. (2004) Towards Participatory Governance: Assessing the transformative possibilities. In Participation: From tyranny to transformation? Edited by S. Hickey and G. Mohan, Zed Books, London, pp. 25-42. 
George, A. (2009) ‘By Papers and Pens, You Can Only Do So Much’: Views about accountability and human resource management from Indian government health administrators and workers, International Journal of Health Planning and Management, 24, pp. 205-224.

George, A., Scott, K., Garimella, S., Mondal, S., Ved, R. And Sheikh, K. (2015) Anchoring Contextual Analysis in Health Policy and Systems Research: A narrative of contextual factors influencing health committees in low and middle income countries, Social Science \& Medicine, 133, pp. 159-167.

Gilson, L. (2015) Michael Lipsky, Street-Level Bureaucracy: Dilemmas of the individual in public service. In The Oxford Handbook of Classics in Public Policy and Administration, edited by S. Balla, M. Lodge and E. Page, Oxford University Press, Oxford, pp. 383-405.

Gilson, L., Palmer, N. and Schneider, H. (2005) Trust and Health Worker Performance: Exploring a conceptual framework using South African evidence, Social Science \& Medicine, 62, pp. 1418-1429.

Government of India (2005) Guidelines for Village Health and Sanitation Committees, SubCentres, PHCs and CHCs, Ministry of Health and Family Welfare.

Hupe, P. and Hill, M. (2007) Street-Level Bureaucracy and Public Accountability, Public Administration, 85 (2), pp. 279-299.

Kaplan B., \& Maxwell J. A. (1994) Qualitative research methods for evaluating computer information systems , in C.E. Aydin \& S J Jay (eds) Evaluating Health Care Information Systems: Methods and Applications ( pp 45-68) Thousand Oaks, CA, Sage

Lipsky, M. (1980) Street-Level Bureaucracy: Dilemmas of the individual in public services, Russell Sage Foundation, New York.

MOHFW. (2011) Annual Report to the People on Health, Government of India, Ministry of Health and Family Welfare, New Delhi, December 2011.

McCoy, D., Hall, J. and Ridge, M. (2012) A Systematic Review of the Literature for Evidence on Health Facility Committees in Low and Middle-Income Countries, Health Policy and Planning, 27, pp. 449-466.

Madon, S., Krishna, S. and Michael, E. (2010) Health Information Systems, Decentralisation and Accountability, Public Administration and Development, 30 (4), pp. 247-260

Magnani, L (2001). Abduction, Reason, and Science: Processes of Discovery and Explanation. Kluwer Academic Plenum Publishers, New York.

Mahmud, S. (2007) "Spaces for Participation in Health Systems in Rural Bangladesh: The experience of stakeholder community groups". In Spaces for Change: The politics of citizen 
participation in new democratic arenas, edited by A. Cornwall and V.S. Coelho, Zed Books, London, pp. 55-76.

May, P.J. and Winter, S.C. (2007) Politicians, Managers, and Street-Level Bureaucrats: Influences on policy implementation, Journal of Public Administration Research and Theory, 19, pp. 455-476.

Meyers, M. and Nielsen, V.L. (2012) Street-level Bureaucrats and the Implementation of Public Policy. In The Sage Handbook of Public Administration, edited by Guy Peters and Jon Pierre, Sage Publications, pp. 305-319.

Mohanty, R. (2007) Gendered Subjects, the State and Participatory Spaces: The politics of domesticating participation in rural India. In Spaces for Change: The politics of citizen participation in new democratic arenas,, edited by A. Cornwall and V.S. Coelho, Zed Books, London, pp. 76-95.

Molyneux, S., Atela, S., Angwenyi, Y. and Goodman, C. (2012) Community Accountability at Peripheral Health Facilities: A review of the empirical literature and development of a conceptual framework, Health Policy and Planning, 27, pp. 541-554.

Myers, M. D (2013) Qualitative Research in Business \& Management, Thousand Oaks, CA, Sage

NRHM. (2011) Update on the ASHA Programme, NRHM,MoHFW, Government of India, New Delhi.

NRHM. (2013) Guidelines for Community Processes. National Rural Health Mission, Government of India.

Nielsen, V.L. (2006) Are Street-Level Bureaucrats Compelled or Enticed to Cope? Public Administration, 84, 4, pp. 861-889.

Nielsen V.L. (2007) Differential Treatment and Communicative Interactions: Why the character of social interaction is important, Law \& Policy, 29, 2, pp. 257-282.

Novo, A. and Leubolt, B. (2005) Participatory Budgeting in Porto Alegre: Social innovation and the dialectic relationship of state and civil society, Urban Studies, 42, 11, pp. 2023-2036.

Pare, L. and Robles, C. (2006) Managing Watersheds and the Right to Water: Indigenous communities in search of accountability and inclusion in Southern Veracruz. In Rights, Resources and the Politics of Accountability, edited by P. Newell \& J. Wheeler, Zed Books, London, pp. 79-101.

Rifkin, S. (2014) Examining the Links between Community Participation and Health Outcome: A review of the literature, Health Policy and Planning, 29, pp. ii98-ii106. 
Roberts, N. (2002) Keeping Public Officials Accountable through Dialogue: Resolving the accountability paradox, Public Administration Review, 62 (6), pp. 658-669.

Roque, S. and Shankland, A. (2007) Participation, Mutation and Political Transition: New democratic spaces in Peri-urban Angola. In Spaces for Change: The politics of citizen participation in new democratic arenas, edited by A. Cornwall \& V.S. Coelho, Zed Books, London, pp. 202-226.

Singh, R. and Purohit, B. (2012) Limitations in the Functioning of Village Health and Sanitation Committees in a North Western State in India, Informational Journal of Medicine and Public Health, 2, 3, pp. 39-46.

Srivastava, A., Gope, R., Nair, N., Rath, S., Rath, S., Sinha, R., Sahoo, P., Biswal, P., Singh, V., Nath, V., Sachdev, H., Skordis-Worrall, J., Haghparash-Biodgoli, H., Costello, A., Prose, A. and Bhattacharyya, S. (2016) Are Village Health Sanitation and Nutrition Committees Fulfilling Their Roles for Decentralised Health Planning and Action? A mixed methods study from rural eastern India, BMC Public Health, 16:59.

Tummers, L.G. and Bekkers, V.J.J.M. (2014) Policy Implementation, Street-level Bureaucracy and the Importance of Discretion, Public Management Review, 16, 4, pp. 527-547.

Veron, R., Williams, G., Corbridge, S. and Srivastava, G. (2006) Decentralised Corruption or Corrupt Decentralization? Community monitoring of poverty alleviation schemes in Eastern India.

Yanow, D., Schwartz-Shea, P. and Freitas, M.J. (2010) Case Study Research in Political Science. In Encyclopedia of Case Study Research, Sage Publications, London, pp. 108-113.

Wilson, A. (2015) India's Village Health, Sanitation and Nutrition Committees: The relationship between committee functioning and village health outcomes in rural Karnataka, MSc. Thesis, Department of International Development, London School of Economics and Political Science. 


\begin{tabular}{|c|c|c|c|c|}
\hline \multicolumn{5}{|c|}{ VHSNC Activities } \\
\hline $\begin{array}{c}\text { Raising health } \\
\text { awareness }\end{array}$ & $\begin{array}{c}\text { Deciding on } \\
\text { fund usage }\end{array}$ & $\begin{array}{c}\text { Self- } \\
\text { organising }\end{array}$ & $\begin{array}{c}\text { Planning \& } \\
\text { Monitoring }\end{array}$ & $\begin{array}{c}\text { Cross-sector } \\
\text { integration }\end{array}$ \\
\hline
\end{tabular}

Table 1: Participant Observation Coding Template 


\begin{tabular}{|l|l|l|l|l|}
\hline $\begin{array}{l}\text { Giving a health } \\
\text { awareness talk }\end{array}$ & $\begin{array}{l}\text { Purchase of } \\
\text { health } \\
\text { equipment }\end{array}$ & $\begin{array}{l}\text { Attendance } \\
\text { register }\end{array}$ & $\begin{array}{l}\text { Planning for } \\
\text { summer months } \\
\text { and festivals }\end{array}$ & $\begin{array}{l}\text { Establishing } \\
\text { communication with } \\
\text { gram panchayat }\end{array}$ \\
\hline $\begin{array}{l}\text { Creating awareness } \\
\text { about the VHSNC } \\
\text { and its aims }\end{array}$ & $\begin{array}{l}\text { Spending on } \\
\text { sanitation and } \\
\text { hygiene }\end{array}$ & $\begin{array}{l}\text { Reorganising } \\
\text { committee } \\
\text { membership }\end{array}$ & $\begin{array}{l}\text { Planning for } \\
\text { government } \\
\text { health surveys }\end{array}$ & $\begin{array}{l}\text { Linkages with primary } \\
\text { health centre }\end{array}$ \\
\hline $\begin{array}{l}\text { Distributing board } \\
\text { about VHSNC in } \\
\text { village }\end{array}$ & $\begin{array}{l}\text { Using fund for } \\
\text { nutrition }\end{array}$ & $\begin{array}{l}\text { Announcing } \\
\text { meeting dates } \\
\text { in advance }\end{array}$ & $\begin{array}{l}\text { Monitoring of } \\
\text { sanitation } \\
\text { infrastructure }\end{array}$ & $\begin{array}{l}\text { Linkages with health } \\
\text { administration for } \\
\text { conduct of surveys }\end{array}$ \\
\hline $\begin{array}{l}\text { House-to-house } \\
\text { visits to spread } \\
\text { health awareness }\end{array}$ & $\begin{array}{l}\text { Using fund for } \\
\text { survey } \\
\text { administration }\end{array}$ & $\begin{array}{l}\text { Recapping of } \\
\text { previous } \\
\text { meeting }\end{array}$ & $\begin{array}{l}\text { Monitoring of } \\
\text { health } \\
\text { equipment }\end{array}$ & $\begin{array}{l}\text { Implementing tasks } \\
\text { following taluk/district } \\
\text { guidelines }\end{array}$ \\
\hline $\begin{array}{l}\text { Promoting } \\
\text { awareness about } \\
\text { nutrition }\end{array}$ & $\begin{array}{l}\text { Using fund for } \\
\text { destitutes }\end{array}$ & $\begin{array}{l}\text { Distributing } \\
\text { items in the } \\
\text { presence of } \\
\text { members }\end{array}$ & $\begin{array}{l}\text { Monitoring } \\
\text { garbage removal }\end{array}$ & $\begin{array}{l}\text { Undertaking activities } \\
\text { that link with wider } \\
\text { government } \\
\text { programmes }\end{array}$ \\
\hline $\begin{array}{l}\text { Creating awareness } \\
\text { about sanitation } \\
\text { for ASHA } \\
\text { outreach }\end{array}$ & $\begin{array}{l}\text { Providing } \\
\text { innoceipt of fund } \\
\text { declaring } \\
\text { balance }\end{array}$ & $\begin{array}{l}\text { Village health } \\
\text { planning }\end{array}$ & $\begin{array}{l}\text { Integrating the work of } \\
\text { health workers and } \\
\text { anganwadi workers }\end{array}$ \\
\hline
\end{tabular}


Table 2 - VHSNC Membership

\begin{tabular}{|c|c|c|c|}
\hline Member & Political/State/Civil & Role in village & Role in VHSNC \\
\hline Gram panchayat member(s) & Political & $\begin{array}{l}\text { In charge of decentralization and local } \\
\text { governance in village }\end{array}$ & $\begin{array}{l}\text { One gram panchayat member is } \\
\text { elected as President of the } \\
\text { VHSNC and is the joint } \\
\text { account holder of the VHSNC } \\
\text { fund }\end{array}$ \\
\hline ASHA(s) & State & Educators and promoters of health & $\begin{array}{l}\text { One ASHA worker serves as } \\
\text { Secretary of the VHSNC and is } \\
\text { the joint account holder of the } \\
\text { VHSNC fund }\end{array}$ \\
\hline Anganwadi worker(s) & State & To combat child hunger and malnutrition & Member \\
\hline $\begin{array}{l}\text { ANM(s) - Auxiliary Nurse } \\
\text { Midwife }\end{array}$ & State & $\begin{array}{l}\text { Multipurpose health worker in charge of } \\
\text { maternal \& child health, family planning, } \\
\text { health \& nutrition education, } \\
\text { environmental sanitation, immunization, } \\
\text { treatment of minor injuries }\end{array}$ & Member \\
\hline $\begin{array}{l}\text { MHW(s) - Male Health } \\
\text { Worker }\end{array}$ & State & $\begin{array}{l}\text { Multipurpose health worker in charge of } \\
\text { communicable diseases, environmental } \\
\text { sanitation, detection of disease outbreaks, } \\
\text { health education }\end{array}$ & Member \\
\hline School teacher & State & Educator in local school & Member \\
\hline Self-help group rep & Civil & To encourage income-generating activity & Member \\
\hline $\begin{array}{l}\text { Scheduled Caste/Scheduled } \\
\text { Tribes rep }\end{array}$ & Civil & $\begin{array}{l}\text { To represent the interests of the SC/ST } \\
\text { population }\end{array}$ & Member \\
\hline $\begin{array}{l}\text { Pregnant women / new } \\
\text { mothers }\end{array}$ & Civil & Child-rearing & Non-member \\
\hline
\end{tabular}


Table 3: VHSNC Meetings Frequency and Attendance

\begin{tabular}{|c|c|c|c|c|c|c|c|c|c|c|c|c|}
\hline & $\begin{array}{l}\# \\
\text { meets }\end{array}$ & $\begin{array}{l}\text { avg } \\
\text { members } \\
\text { per meet }\end{array}$ & $\begin{array}{l}\text { \# } \\
\text { marginalised }\end{array}$ & $\begin{array}{l}\# \\
\text { meets }\end{array}$ & $\begin{array}{l}\text { avg } \\
\text { members } \\
\text { per meet }\end{array}$ & $\begin{array}{l}\text { \# } \\
\text { marginalised }\end{array}$ & $\begin{array}{l}\# \\
\text { meets }\end{array}$ & $\begin{array}{l}\text { avg } \\
\text { members } \\
\text { per meet }\end{array}$ & $\begin{array}{l}\text { \# } \\
\text { marginalised }\end{array}$ & $\begin{array}{l}\text { \# } \\
\text { meets }\end{array}$ & $\begin{array}{l}\text { avg } \\
\text { members } \\
\text { per meet }\end{array}$ & $\begin{array}{l}\text { \# } \\
\text { marginalised }\end{array}$ \\
\hline Changachalli & 3 & 9 & 50 & 5 & 10 & 51 & 1 & 9 & 63 & 5 & 17 & 88 \\
\hline Dasanahundi & 5 & 8 & 58 & 6 & 8 & 62 & 4 & 14 & 81 & 7 & 19 & 76 \\
\hline Gangavadi & 3 & 9 & 62 & 1 & 9 & 67 & 2 & 15 & 83 & 3 & 16 & 63 \\
\hline Ganiganoor & 4 & 8 & 65 & 7 & 18 & 81 & 2 & 16 & 77 & 7 & 16 & 80 \\
\hline Gumballi & 5 & 6 & 41 & 4 & 18 & 83 & 2 & 18 & 75 & 6 & 17 & 75 \\
\hline Hegadehundi & 3 & 9 & 25 & 4 & 9 & 64 & 1 & 14 & 72 & 6 & 17 & 73 \\
\hline Komanapura & 3 & 9 & 58 & 7 & 10 & 69 & 2 & 12 & 82 & 6 & 17 & 76 \\
\hline Krishnapura & 3 & 9 & 68 & 7 & 11 & 63 & 2 & 13 & 64 & 6 & 16 & 81 \\
\hline Uppinamole & 5 & 7 & 54 & 5 & 15 & 64 & 0 & 0 & 0 & 5 & 18 & 72 \\
\hline Vadagere & 4 & 7 & 54 & 6 & 12 & 56 & 2 & 10 & 61 & 6 & 15 & 70 \\
\hline YK Mole & 7 & 8 & 68 & 6 & 10 & 69 & 3 & 17 & 80 & 9 & 18 & 76 \\
\hline Yargamballi & 5 & 9 & 54 & 7 & 21 & 66 & 3 & 20 & 83 & 8 & 19 & 70 \\
\hline
\end{tabular}




\section{Figure Captions}

Figure 1 - Conceptualizing Accountability in VHSNCs

Figure 2 - Trends in VHSNC Activities

Figure 3 - Interpreting Accountability in VHSNCs as Stages of Maturity

\footnotetext{
' 16/6/2015, Dasanahundi village resident VHSNC member

ii 16/6/2015, ANM Yargamballi

iii 16/6/2015, ST representative VHSNC member

iv $9 / 11 / 2015$, school teacher VHSNC member at Komanapura village meeting

v 16/6/2015, ASHA worker Gangavadi
} 
Figure 1: Conceptualising Accountability in the VHSNCs

GOVERNMENT
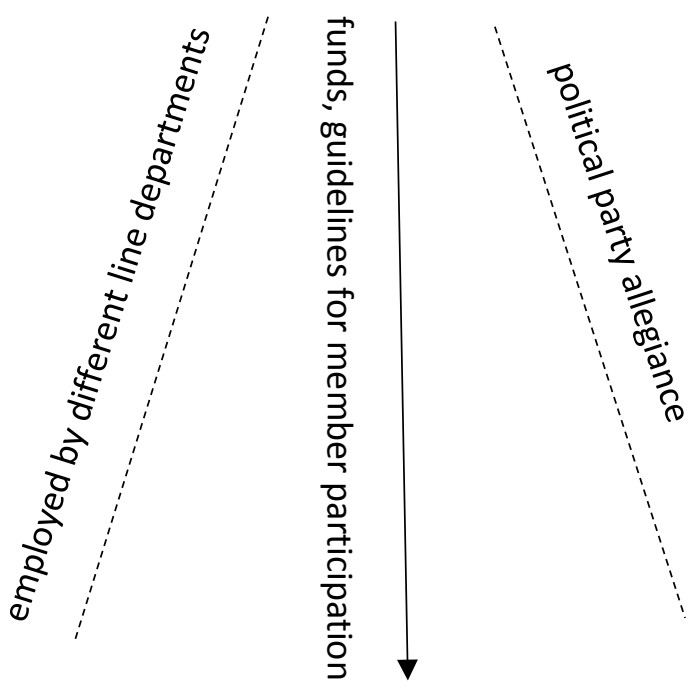

VHSNC's accountability environment

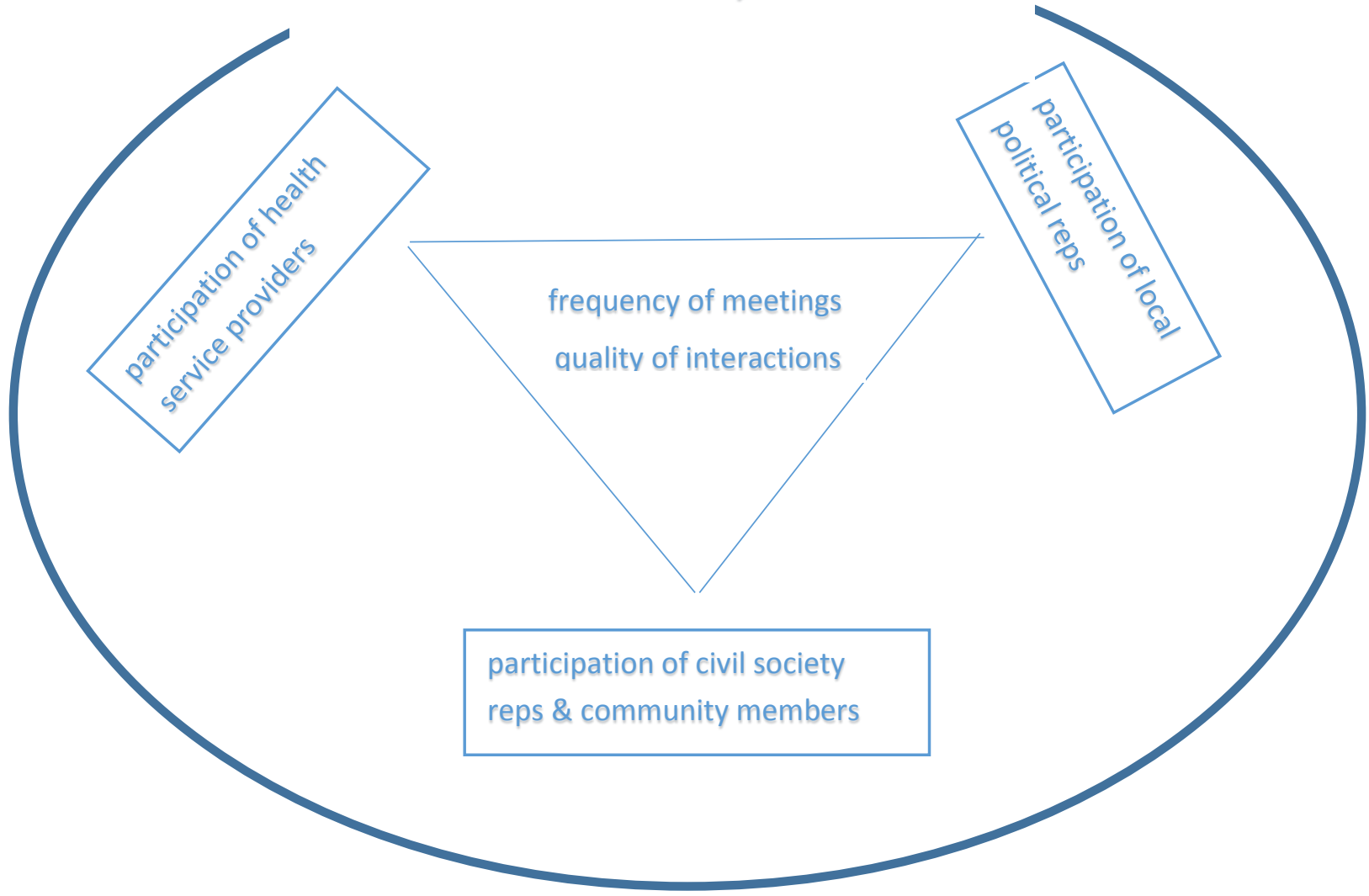


Figure 2: Trends in VHSNC activities. The p values shown are from the multilevel regression model described in the text, and indicate that health awareness, self-organising and planning and monitoring activities $(\mathrm{p}<0.00001)$, but not united grant usage and cross-sector collaboration, increased over time across all the study villages.

a.

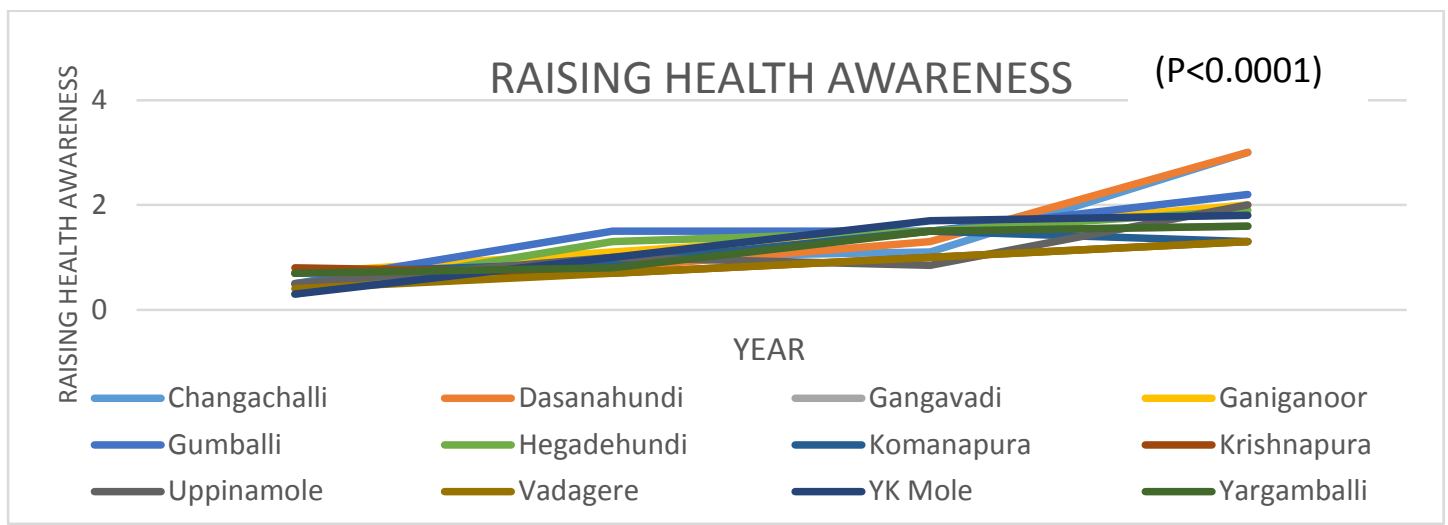

b.

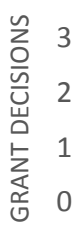

UNTIED GRANT USAGE

c.

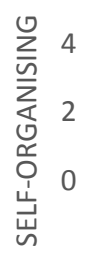

SELF-ORGANISING

$(\mathrm{P}<0.0001)$

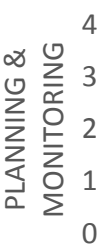

PLANNING \& MONITORING

$(P<0.0001)$

d.

e.

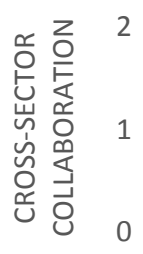

CROSS-SECTOR INTEGRATION

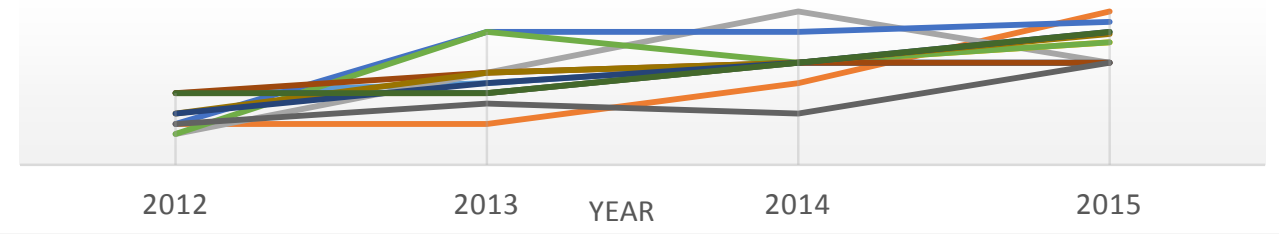


Figure 3: Interpreting Accountability in VHSNCs as Stages of Maturity

Initial
identification \&
enrolment of
members

Informed VHSNC

membership and

regular meetings
Increase in raising health awareness \& local village health priorities

Improving effective fund utilisation

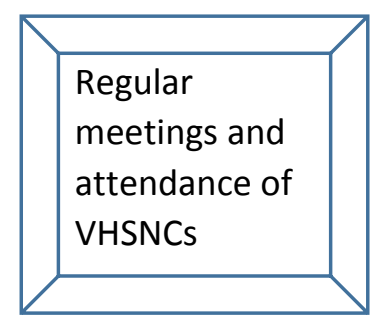

Learning how to conduct meetings and to disseminate health awareness

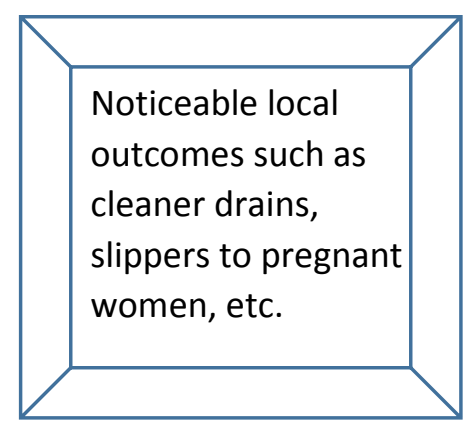

Regular meetings

Engaging with planning and monitoring village health and agreed practices

Regular cross-sectoral links with panchayat and health bodies 


\section{APPENDIX - Details of FGDs and Interviews}

\begin{tabular}{|l|l|l|l|}
\hline FGD/Interview & \multicolumn{1}{|c|}{ Respondent(s) } & \multicolumn{1}{|c|}{ Location } & \multicolumn{1}{|c|}{ Date } \\
\hline FGD & $\begin{array}{l}\text { 15 in total Dasanahundi VHSNC members } \\
\text { including: President (gram panahcyat member), } \\
\text { Secretary (ASHA worker), health workers, 2 } \\
\text { mother and child nutrition workers, waterman, } \\
\text { 2 self-help group reps, scheduled tribe rep, 2 } \\
\text { interested members, 2 pregnant ladies, 2 } \\
\text { lactating mothers }\end{array}$ & Dasanahundi & $16 / 6 / 2015$ \\
\hline FGD & $\begin{array}{l}\text { 15 in total Gangavadi VHSNC members } \\
\text { including: President (gram panchayat member), } \\
\text { Secretary (ASHA worker), health worker, 2 } \\
\text { mother and child nutrition workers, school } \\
\text { teacher, 2 self-help group reps, scheduled tribe } \\
\text { rep, 2 interested members, 2 pregnant ladies, 3 } \\
\text { lactating mothers }\end{array}$ & & \\
\hline Interview & Health worker 1 & Gumballi & $16 / 6 / 2015$ \\
\hline Interview & Health worker 2 & Yargamballi & $16 / 6 / 2015$ \\
\hline Interview & Field researcher 1 & Yargamballi & $16 / 6 / 2015$ \\
\hline Interview & Field researcher 2 & BR Hills & $15 / 7 / 2015$ \\
\hline
\end{tabular}

Focus Group Discussion Questions

1. Can you tell us a little about the VHSNCs? How long has this committee been functioning and how long have you been members?

2. What do you think is the role and influence of the VHSNC in the health of the village?

3. How does your VHSNC function in terms of meetings and organisation?

4. What things has the VHSNC been able to do well? How did that happen?

5. Have you had any challenges with the functioning of your VHSNC? Why?

6. In the future, how could the performance of your VHSNC be improved?

Interview Questions

1. Can you tell me a little about your background and how long you have been working with the $\operatorname{VHSNC}(\mathrm{s})$ ?

2. What has been your experience working with the VHSNC(s)?

3. What do you see as the key characteristics of a successful VHSNC? What kinds of things influence the functioning of a VHSNC and why?

4. Do you think the VHSNCS are influencing village health? Explain how.

5. I have noticed in my research that Dasanahundi has been meeting very regularly and functioning well over the last few years while Gangavadi has not met as often. As someone who works with both VHSNCs why is this?

6. What can be done to strengthen the performance of VHSNCs which are struggling? 